\title{
Molecular Analysis of Abnormal Pyruvate Dehydrogenase in a Patient with Thiamine-Responsive Congenital Lactic Acidemia
}

\author{
ETSUO NAITO, MICHINORI ITO, EIJI TAKEDA, ICHIRO YOKOTA, \\ SATOSHI YOSHIJIMA, AND YASUHIRO KURODA \\ Department of Pediatrics, School of Medicine, University of Tokushima, Tokushima 770, Japan \\ [E.N., M.I., E.T., I.Y., Y.K./ and Department of Pediatrics, Saiseikai Nakatsu Hospital, \\ Osaka 530, Japan [S.Y.]
}

\begin{abstract}
A patient who responded to thiamine therapy with re-
duction of lactate in the blood and cerebrospinal fluid and
clinical improvement was studied. Cultured lymphoblas-
toid cells of this patient were found to show reduced
activities of pyruvate dehydrogenase complex (PDHC) and
pyruvate dehydrogenase, decreased affinity of PDHC for
thiamine pyrophosphate, and defective activation of PDHC
by pyruvate dehydrogenase phosphatase. PDHC defi-
ciency in fibroblasts and biopsied muscle of this patient
was also due to the decreased affinity of PDHC for thia-
mine pyrophosphate. A mutation in the E $\mathrm{E}_{1} \alpha$ subunit con-
taining the thiamine binding site and serine phosphoryla-
tion site regulating the activation/inactivation of PDHC
was characterized by the polymerase chain reaction and
\end{abstract}
Congenital lactic acidemia is known to be heterogeneous and to be caused by genetically determined defects in the activities of a variety of enzymes. It is most often caused by a defect in the PDHC, which catalyzes the oxidative decarboxylation of pyruvate (1). The PDHC is a multienzyme system composed of $E_{1}$, dihydrolipoyltransacetylase, and dihydrolipoyldehydrogenase. $E_{1}$ is composed of two nonidentical subunits, $E_{1} \alpha$ and $E_{1} \beta$ and has a tetrameric structure, $\alpha_{2} \beta_{2}$. One mechanism for regulation of PDHC activity is phosphorylation/dephosphorylation of serine residues on the $E_{1} \alpha$ subunit (2). The binding site for TPP, which is an essential cofactor for PDHC, is also thought to be between the $E_{1} \alpha$ and $E_{1} \beta$ subunits (3). Therefore, the $E_{1} \alpha$ subunit plays an important role in thiamine-dependent decarboxylation of pyruvate.

\footnotetext{
Received November 16, 1993; accepted April 20, 1994.

Correspondence and reprint requests: Etsuo Naito, M.D., Department of Pe diatrics, School of Medicine, University of Tokushima, Kuramoto Cho 3 Tokushima 770, Japan.

Supported in part by grants from the National Center of Neurology and Psychiatry (NCNP) of the Ministry of Health and Welfare (2-A) and from the Ministry of Education, Science and Culture, Japan (05670680).
}

DNA sequencing. A single $A \rightarrow G$ transition was identified at position 131, resulting in the substitution of Arg- 44 for His-44. This mutation must be a de novo mutation because it was not found in either parent's genomic DNA. In this study, we have obtained the first evidence at the molecular level for a mutation of thiamine-responsive PDHC deficiency. (Pediatr Res 36: 340-346, 1994)

Abbreviations
PDHC, pyruvate dehydrogenase complex
E, pyruvate dehydrogenase
TPP, thiamine pyrophosphate
DCA, sodium dichloroacetate
CSF, cerebrospinal fluid

Many patients with congenital lactic acidemia have been reported to show reduction of blood lactate and clinical improvement in response to thiamine administration $(4,5)$. This response is thought to occur because the mutant enzyme has decreased affinity for thiamine or because thiamine stabilizes the abnormal enzyme, but it has not been studied in detail. In this article, we described for the first time the biochemical and molecular analysis of thiamine dependency in a patient with congenital lactic acidemia.

\section{METHODS}

Case report. The patient was the second child of unrelated parents and was born after $37 \mathrm{wk}$ of gestation after a normal pregnancy and delivery. His birth weight was $1928 \mathrm{~g}$, and he showed hypotonia and poor feeding from birth. The family history was negative for neurologic disease. He was admitted to the hospital for further examination at 2 mo of age. On admission, the blood lactate $(10.2 \mathrm{mM})$ to blood pyruvate $(0.79 \mathrm{mM})$ ratio was 13:1. The concentrations of lactate and pyruvate in the CSF were significantly elevated, being 11.5 and $1.1 \mathrm{mM}$, 
respectively. Amino acid analysis of plasma showed an elevated alanine level at $1840 \mu \mathrm{mol} / \mathrm{L}$ (normal range, $220-490 \mu \mathrm{mol} / \mathrm{L}$ ). Repeat blood glucose concentrations and other routine blood studies were normal. The findings on EEG and ECG were unremarkable. Muscle biopsy specimens showed no significant morphologic changes. No ragged red fibers were found. Administration of thiamine was started at the age of $3 \mathrm{mo}$. He responded to thiamine therapy $(100 \mathrm{mg} / \mathrm{d}, 25 \mathrm{mg} / \mathrm{kg} / \mathrm{d})$ with reduction in the concentrations of lactate in the blood $(5.9 \mathrm{mM})$ and CSF $(6.0 \mathrm{mM})$ as shown in Figure 1. When the patient was 5 mo of age, the concentrations of lactate $(6.9 \mathrm{mM})$ and pyruvate $(0.65 \mathrm{mM})$ in the blood were elevated again. Increase of doses of thiamine $(50$ $\mathrm{mg} / \mathrm{kg} / \mathrm{d}$ ) led to reduction of blood lactate and pyruvate (5.4 and $0.64 \mathrm{mM}$, respectively). Head computed tomography scan and magnetic resonance imaging scan when the patient was 8 mo of age showed no significant changes except mild atrophy. The finding on EEG was unremarkable. However, the concentrations of lactate $(6.3 \mathrm{mM})$ and pyruvate $(0.75 \mathrm{mM})$ in the blood increased again. When the patient was 9 mo of age, high doses of thiamine $(600 \mathrm{mg} / \mathrm{d}, 100 \mathrm{mg} / \mathrm{kg} / \mathrm{d})$ led to marked reductions of lactate in the blood $(3.0 \mathrm{mM})$ and CSF $(3.1 \mathrm{mM})$, as shown in Figure 1. An alanine concentration was also reduced to $330 \mu \mathrm{mol} / \mathrm{L}$. After 6 mo of thiamine treatment, the patient showed an improvement of feeding and hypotonia and then gained weight and developed head control. Thiamine therapy of this patient led to the clinical improvement, consistent with the reduction of lactate.

Radioisotopes and chemicals. $\left[1-{ }^{14} \mathrm{C}\right]$ pyruvate was obtained from NEN Research Products (Boston, MA). $\left[{ }^{35} \mathrm{~S}\right]$ deoxy ATP was purchased from Amersham International (Bucks, UK). DCA was obtained from Tokyo Kasei Kogyo (Tokyo, Japan). Other compounds were from Sigma Chemical Co. (St. Louis, MO).

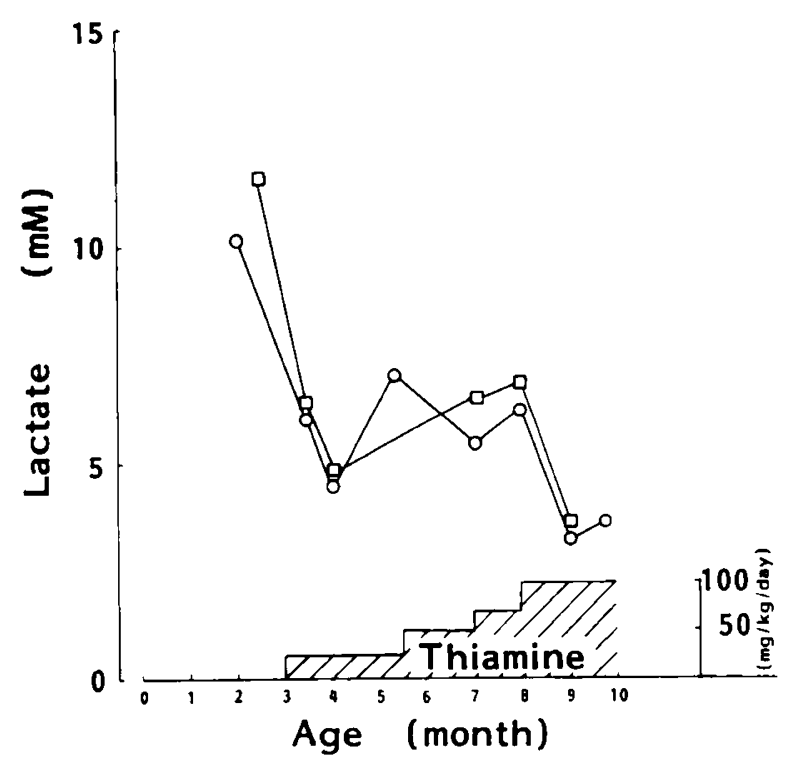

Figure 1. Effect of thiamine on the concentration of lactate in blood and $\operatorname{CSF}$ of a thiamine-responsive patient. Shown is the change of lactate concentration in blood $(O)$ and $\operatorname{CSF}(\square)$.
Cell culture. Lymphoblastoid cell lines derived from the thiamine-responsive patient, his parents, and 16 diseasefree Japanese persons were established after incubation with EBV and cyclosporin A as described by Anderson and Gusella (6). Lymphoblastoid cells were grown in RPMI 1640 medium supplemented with 15\% FCS (Gibco Laboratories, Grand Island, NY). Fibroblasts were grown in Eagle's minimal essential medium (Nissui, Tokyo, Japan) with $10 \%$ FCS. Confluent cells were harvested and washed twice with PBS.

Assay of rate of decarboxylation of $\left[1-{ }^{14} \mathrm{C}\right]$ pyruvate. The rate of decarboxylation of $\left[1-{ }^{14} \mathrm{C}\right]$ pyruvate was measured by a modification of the method of Naito et al. (7). Briefly, lymphoblastoid cells were harvested, washed, and suspended with PBS. The cells were incubated in 0.2 $\mathrm{mL}$ of PBS containing $2.5 \mathrm{mmol} / \mathrm{L}\left[1-{ }^{14} \mathrm{C}\right]$ pyruvate $(0.1$ $\mathrm{mCi} / \mathrm{mmol})$ with or without thiamine- $\mathrm{HCl}(4 \mathrm{mM})$ and with or without TPP $(1 \mathrm{mM})$ in closed vessels at $37^{\circ} \mathrm{C}$ for $1 \mathrm{~h}$.

Assays of PDHC and other enzymes. Three kinds of activities of PDHC in cultured lymphoblastoid cells and cultured fibroblasts were determined by a modification of the method of Naito et al. (7). For determination of the DCA-activated activity, the harvested cells were incubated for $30 \mathrm{~min}$ at $37^{\circ} \mathrm{C}$ in PBS containing $5 \mathrm{mM}$ DCA to activate PDHC. The incubation was stopped by stop solution ( $30 \mathrm{mM} \mathrm{NaF}, 30 \mathrm{mM}$ DCA, $6 \mathrm{mM}$ EDTA), and then ice-cold homogenizing buffer was added to the cell pellet obtained by centrifugation. The suspension was frozen rapidly, and then the PDHC activity was determined as described previously (7). Native activity was measured without preincubation of $5 \mathrm{mM}$ DCA. For assay of total activity, the homogenate was preincubated with a partially purified preparation of a broad specificity protein phosphatase from rabbit liver (8) and $3.7 \mathrm{mM}$ $\mathrm{MnCl}_{2}$ for $30 \mathrm{~min}$ at $37^{\circ} \mathrm{C}$, and then the PDHC activity was measured as described above. The PDHC activities in the presence of various concentrations of TPP were measured after their additions to the assay mixture. The activity of $E_{1}$ in cultured lymphoblastoid cells was determined by the method of Chuang et al. (9). The activity of DCA-activated $E_{1}$ was measured after preincubation with $5 \mathrm{mM}$ DCA for $30 \mathrm{~min}$ as described above. The $E_{1}$ phosphatase activities in lymphoblastoid cells were determined by the method of Ito et al. (10). The pyruvate carboxylase and phosphoenolpyruvate carboxykinase activities in cultured fibroblasts were determined by the method of Atkin et al. (11).

Immunoblot analysis. PDHC was purified from ox heart, and rabbit antibodies were prepared against PDHC, $\mathrm{E}_{1} \alpha$, and $E_{1} \beta$ proteins (12). Immunoblot analysis was performed with these antibodies as described previously (12).

Amplification of human $E_{l} \alpha$ and $E_{l} \beta m R N A$, subcloning, and DNA sequencing. RNA isolation from lymphoblastoid cells and cDNA synthesis were performed (13). Sets of sense and antisense oligonucleotides were designed so that the PCR products generated covered the entire nor- 
mal human cDNA sequence, and each contained an EcoRI restriction site for subcloning. The synthetic oligonucleotides for $\mathrm{E}_{1} \alpha$ were PDHA-A, PDHA-B, PDHA-C, and PDHA-D as described previously (13). The synthetic oligonucleotides for $\mathrm{E}_{1} \beta$ were PDHB-5 (5'-GGAATTCGATAGAGGACACGACCAAG-3') and PDHB-3 (5' -ATAAATTTCAACGAATTCATATTCAAGTCC-3') selected according to the human $E_{1} \beta$ cDNA sequence $(14,15)$. Thirty-five cycles of the polymerase chain reaction were performed with a GeneAmp DNA amplification reagent kit (Perkin-Elmer Cetus, Norwalk, CT). One cycle consisted of denaturation at $94^{\circ} \mathrm{C}$ for $1 \mathrm{~min}$, annealing at $55^{\circ} \mathrm{C}$ for $1 \mathrm{~min}$, and extension at $72^{\circ} \mathrm{C}$ for $1 \mathrm{~min}$. Subcloning and DNA sequencing with $\left[{ }^{35}\right.$ S]deoxy ATP were performed as described previously (13).

Analysis of genomic DNA. Genomic DNA was isolated from cultured lymphoblastoid cells by the proteinase $\mathrm{K}$ method (13). Specific amplification of genomic DNA encompassing the region of a point mutation detected in the mRNA of the $E_{1} \alpha$ subunit of this patient was attempted with oligonucleotides PA3F (5'-TGGAGGATAATAACTACCTTATTCATTT-3') and PA3R (5'-ACAGTTCCACCACAAACCTACCAC-3'). These primers were selected according to the human $\mathrm{E}_{1} \alpha$ genomic DNA sequence (16). The DNA amplified by PCR were digested with NaeI.

Protein determination. Protein concentrations during purification of ox PDHC and SDS-PAGE were determined by the method of Bradford (17). The protein concentrations of other samples were measured by the method of Lowry et al. (18) with BSA as a standard.

Statistical analysis. Statistical significance was determined by $t$ test.

\section{RESULTS}

Decarboxylation of $\left[1{ }^{14} \mathrm{C}\right]$ pyruvate in intact lymphoblastoid cells. Intact lymphoblastoid cells from normal subjects and the thiamine-responsive patient incubated with $\left[1-{ }^{14} \mathrm{C}\right]$ pyruvate alone showed decarboxylation rates of 78.6 and $15.9 \mathrm{nmol} / \mathrm{h} / \mathrm{mg}$ of protein, respectively, indicating an $80 \%$ decrease in the rate in the thiamineresponsive variant cells. Addition of a high concentration $(4 \mathrm{mM})$ of thiamine- $\mathrm{HCl}$ to intact normal and thiamineresponsive cells increased the decarboxylation rates of
80.9 and $35.2 \mathrm{nmol} / \mathrm{h} / \mathrm{mg}$ of protein, respectively, resulting in the increase of the decarboxylation rates by 2 and $121 \%$, respectively. Addition of a high concentration (1 $\mathrm{mM}$ ) of TPP to intact normal and thiamine-responsive cells increased the decarboxylation rates of 85.0 and 40.3 $\mathrm{nmol} / \mathrm{h} / \mathrm{mg}$ of protein, respectively, resulting in the increase of the decarboxylation rates by 8 and $153 \%$, respectively.

Activities of PDHC and other enzymes. The activities of the PDHC in cultured lymphoblastoid cells from normal subjects and the patient were assayed in three different conditions (native, DCA activated, and total) and at two different concentrations of TPP $\left(0.4 \mathrm{mM}\right.$ and $1 \times 10^{-4}$ $\mathrm{mM}$ ) (Table 1). When assayed in the presence of $0.4 \mathrm{mM}$ TPP, the DCA-activated activity of normal controls was 2 -fold of native activity, whereas the DCA-activated activity of the patient was almost the same activity in native state, indicating that PDHC of this patient was not sufficiently activated by only his own endogenous $E_{1}$ phosphatase; the total activity, measured after in vitro activation with an excess amount of a broad specificity protein phosphatase, was within the normal range, indicating that PDHC in this patient was activated by the large amount of exogenous $E_{1}$ phosphatase. Furthermore, the activity of the $E_{1}$ phosphatase in this patient was within normal range (the patient had 226.8 and controls had $204.4 \pm 48.2$ $\mathrm{mU}$ PDHC activated $/ \mathrm{min} / \mathrm{mg}$ protein). These results indicated that this patient had a disorder of the mechanism for activation of PDHC except $E_{1}$ phosphatase. In the presence of $1 \times 10^{-4} \mathrm{mM}$ TPP, corresponding to the TPP concentration within normal human blood cells, all three activities of PDHC of this patient were extremely low, although no difference was observed in the PDHC activities of control cells in the presence of $0.4 \mathrm{mM}$ and $1 \times$ $10^{-4} \mathrm{mM}$ TPP. Furthermore, the activities of PDHC of his parents were within normal range in the presence of either $0.4 \mathrm{mM}$ or $1 \times 10^{-4} \mathrm{mM}$ TPP (data not shown). Pyruvate carboxylase and phosphoenolpyruvate carboxykinase activities of cultured fibroblasts of this patient were normal (data not shown).

Affinity of PDHC for TPP. For further explanation of why thiamine had a therapeutic effect in this patient and the addition of thiamine- $\mathrm{HCl}$ or TPP to intact lymphoblastoid cells from this patient increased the rate of decarboxylation of $\left[1-{ }^{14} \mathrm{C}\right]$ pyruvate, we investigated the

Table 1. Activities of PDHC in lymphoblastoid cells*

\begin{tabular}{|c|c|c|c|}
\hline & \multicolumn{3}{|c|}{$\mathrm{PDHC}(\mathrm{nmol} / \mathrm{min} / \mathrm{mg}$ protein $)$} \\
\hline & Native & DCA activated & Total \\
\hline \multicolumn{4}{|c|}{ With $0.4 \mathrm{mM}$ TPP } \\
\hline Patient & $1.41 \pm 0.26(3)$ & $1.41 \pm 0.11 \dagger(4)$ & $3.13 \pm 0.41(4)$ \\
\hline With $1 \times 10^{-4} \mathrm{mM}$ TPP & $0.06 \pm 0.02 \dagger(3)$ & $0.06 \pm 0.05 \dagger(3)$ & $0.21 \pm 0.12+(3)$ \\
\hline Controls & $1.96 \pm 0.29 \dagger(3)$ & $3.90 \pm 0.34+(4)$ & $4.19 \pm 0.29 \dagger(4)$ \\
\hline
\end{tabular}

$*$ Values are means \pm SD with the number of determinations in parentheses.
$\dagger p<0.001 v s$ controls. 
affinities of normal and mutant PDHC for TPP. As shown in Figure $2 A$, normal cells showed approximately $50 \%$ of the full PDHC activity in the absence of TPP, and addition of $1 \times 10^{-5} \mathrm{mM}$ TPP restored the full activity, the PDHC activity being constant at concentrations of more than $1 \times 10^{-5} \mathrm{mM}$ TPP. However, cells from the thiamine-responsive patient showed extremely low PDHC activities with TPP concentrations of 0 to $1 \times 10^{-3} \mathrm{mM}$ and exponential increase of activity with TPP concentration above $1 \times 10^{-3} \mathrm{mM}$. Addition of a high concentration $(0.4 \mathrm{mM})$ of TPP restored up to $35 \%$ of the full PDHC activity of normal cells. These data indicated that the PDHC of this patient showed decreased affinity for TPP.
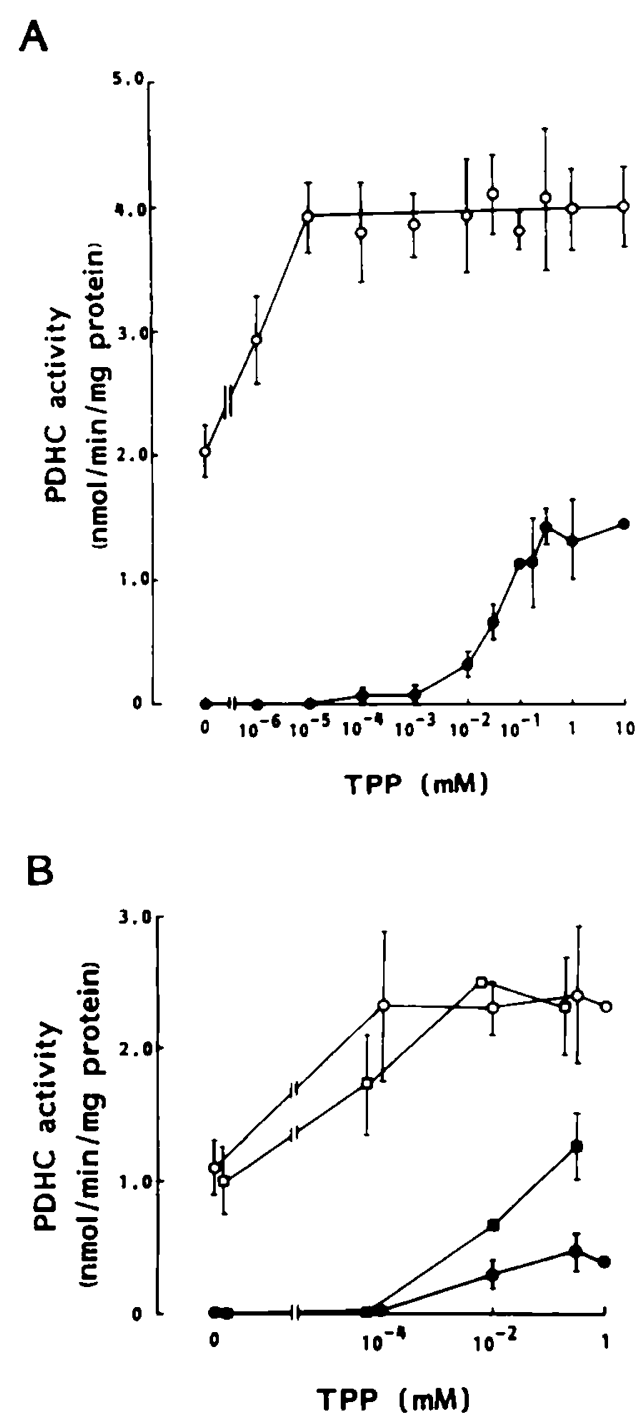

Figure 2. Effect of TPP on the activity of DCA-activated PDHC in disrupted lymphoblastoid cells, disrupted fibroblast cells, and biopsied muscle from normal subjects and a thiamine-responsive patient. $A$, Activity of PDHC in disrupted lymphoblastoid cells was measured at various concentrations of TPP. Shown are normal controls $(O)$ and a thiamine-responsive patient (ソ). $B$, Activity of DCA-activated PDHC in disrupted fibroblasts and activity of native PDHC in biopsied muscle were measured at various concentrations of TPP. Fibroblasts $(O)$ and biopsied muscle $(\square)$ of normal subjects, and fibroblasts $(-)$ and biopsied muscle $(\boldsymbol{\square})$ of the thiamine-responsive patient are shown.
The PDHC activities of both fibroblasts and biopsied muscle from this patient strictly depended on the concentration of TPP (Fig. 2B). In normal controls, almost full activities of PDHC were observed in the presence of TPP at concentrations of more than $1 \times 10^{-4} \mathrm{mM}$. However, the PDHC activities of specimens from the patient in the presence of $1 \times 10^{-4} \mathrm{mM}$ TPP were extremely low, similar to that of his lymphoblastoid cells.

Affinity of $\boldsymbol{E}_{\boldsymbol{l}}$ for $\boldsymbol{T P P}$. To investigate the affinity of $\mathrm{E}_{1}$ for TPP, we measured the activities of DCA-activated $\mathrm{E}_{1}$ in the presence of various concentrations of TPP (Fig. 3). The activity of DCA-activated $E_{1}$ of controls showed approximately $30 \%$ of the full activity in the absence of TPP, and addition of $1 \times 10^{-4} \mathrm{mM}$ TPP restored almost full activity. In contrast, the activity of DCA-activated $E_{1}$ of the patient was extremely low in the presence of $1 \times$ $10^{-4} \mathrm{mM}$ TPP, and addition of a high TPP concentration $(0.2 \mathrm{mM})$ was needed to restore $30 \%$ of the average activity of controls. Thus, the $E_{1}$ of this patient also showed decreased affinity for TPP.

Immunoblot analysis. Immunoblot analyses with anti$E_{1} \alpha$ and anti-E $E_{1} \beta$ antibodies showed that the levels of $E_{1} \alpha$ and $E_{1} \beta$ in this patient were similar to those in normal controls (Fig. 4). Immunoblot analysis with antiPDHC antibody revealed no abnormalities of other components (data not shown).

Characterization of the mutation. We sequenced $E_{1} \alpha$ cDNA from the patient and a normal subject and found

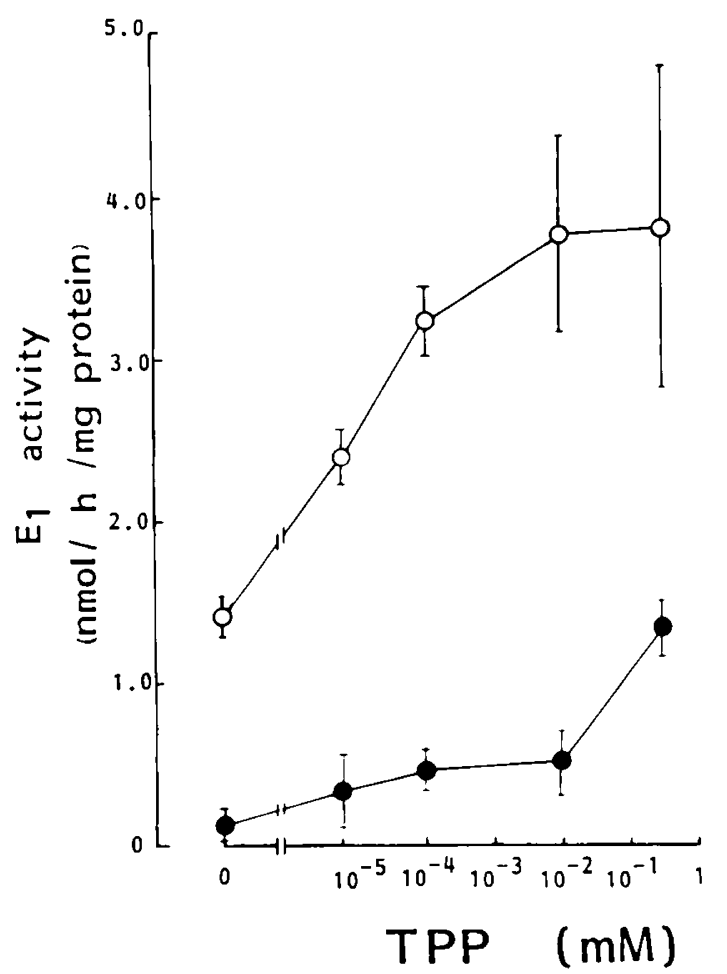

Figure 3. Effect of TPP on the activity of DCA-activated $E_{1}$ in disrupted lymphoblastoid cells from normal subjects and the thiamineresponsive patient. The activity of DCA-activated $E_{1}$ in disrupted lymphoblastoid cells was measured at various concentrations of TPP. Shown are normal controls $(\bigcirc)$ and the thiamine-responsive patient (O). 
A

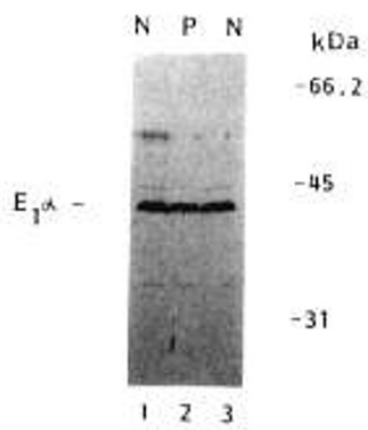

B

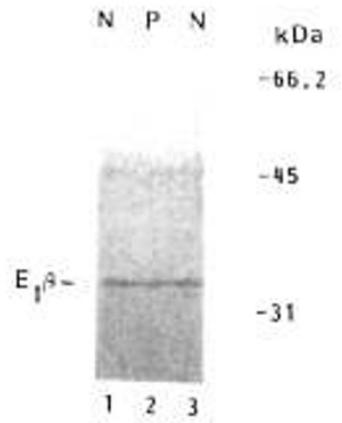

Figure $6 A$. The size of the product of this amplification was expected to be $233 \mathrm{bp}$. When digested with NaeI, the 233-bp fragment amplified from the patient's DNA yielded one short band (186 bp) and unclear band ( $47 \mathrm{bp}$ ) (Fig. 6B), whereas the 233-bp fragment amplified from normal genomic DNA remained intact. The 233-bp fragments amplified from the parents of this patient were also not digested with NaeI. This exon 3 region has been analyzed in more than 30 individuals, including normal control subjects and other patients with PDHC deficiency, and no other example of this base substitution has been found.

\section{DISCUSSION}

Figure 4. Immunoblot analysis of $E_{1}$ proteins in disrupted lymphoblastoid cells from normal subjects and the patient. $E_{1}$ immunoreactive protein was detected by the immunoblot technique with anti- $E_{1} \alpha$ antibody $(A)$ or anti- $\mathrm{E}_{1} \beta$ antibody $(B)$. The positions of $\mathrm{E}_{1} \alpha$ protein $\left(\mathrm{M}_{\mathrm{r}} 42\right.$ $\mathrm{kD})$ and $E_{1} \beta$ protein $\left(M_{r} 36 \mathrm{kD}\right)$ are indicated on the left. The samples were derived from normal controls (lanes $l$ and 3 ) and the thiamineresponsive patient (lane 2).

only one mutation in the second position of codon 44 (Fig. 5). The mutation, substitution of a $G$ nucleotide for an $A$, changed the amino acid histidine to arginine $(\mathrm{CAC} \rightarrow \mathrm{CGC})$. This mutation was therefore designated as H44R. This nucleotide substitution created a restriction site for NaeI (GCCGGC). Subcloning and sequencing of four other clones indicated that the patient had only one amino acid change of H44R for $E_{1} \alpha \mathrm{cDNA}$. The amplified segment corresponding to the $E_{1} \beta$ cDNA of the patient had a normal length, and no change occurred in its amino acid sequence.

Identification of the $A \rightarrow G-131$ transition in genomic DNA. For identification of the $A \rightarrow G-131$ transition in genomic DNA, an exon 3 segment of genomic DNA was amplified by PCR with primers PA3F and PA3R as illustrated in
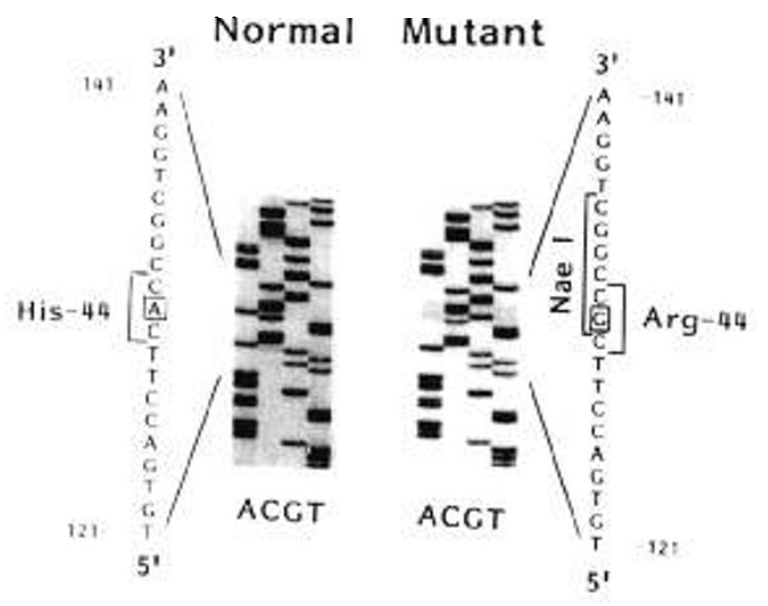

Figure 5. Sequence analysis of cDNA synthesized and amplified from mRNA obtained from lymphoblastoid cells of normal subjects and the patient. Results of nucleotide sequencing of the normal cDNA and the mutant cDNA are shown. The nucleotide residue involved in the mutation is boxed. A-131 in the normal cDNA is replaced by G in the mutant cDNA, resulting in His $\rightarrow$ Arg substitution at the 44th position of the $E_{1} \alpha$. This nucleotide substitution created a restriction site for Nael (GCCGGC) as shown by the solid line.

Many reports of clinical response to thiamine in patients with congenital lactic acidemia have been published, but most cases have not been characterized biochemically to be certain that true thiamine dependence exists. In this study, the clinical thiamine response in our patient was well confirmed by in vitro studies showing a thiamine-responsive functional PDHC defect in several different cell types. Furthermore, we have obtained the

A

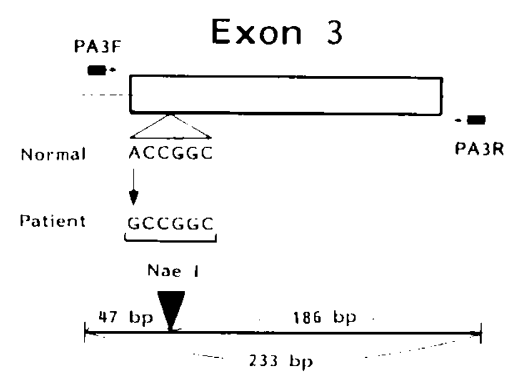

B

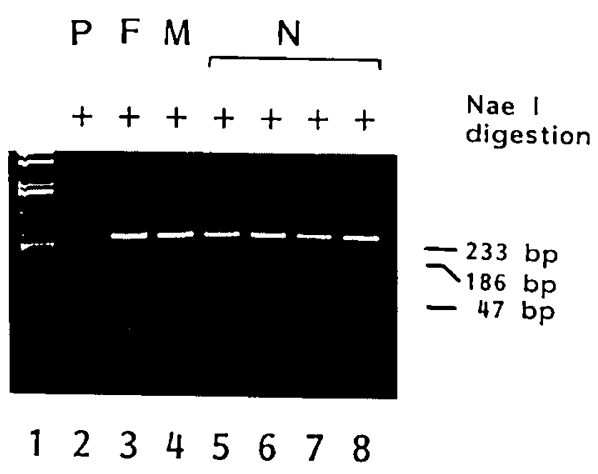

Figure 6. NaeI digestion of the PCR-amplified products from genomic DNA from cultured cells of normal subjects and the patient. The open box depicts exon 3 of the $E_{1} \alpha$-gene. Solid boxes with arrows indicate the orientations and regions of primers used for PCR amplification $(A)$. Electrophoretic separation of the restriction fragments from the PCRamplified products of exon 3 of $E_{1} \alpha$ genomic DNA with NaeI $(B)$. Shown are PCR-amplified products digested with NaeI (lanes 2-8). The DNA samples were derived from genomic DNA of the patient (lane 2), the patient's father (lane 3), the patient's mother (lane 4), and normal controls (lanes $5-8$ ). The molecular weight markers shown in lane I were the PstI-digested fragments of $\lambda$ DNA. 
first evidence at the molecular level for a mutation of thiamine-responsive PDHC deficiency.

Cultured lymphoblastoid cells derived from our patient showed reduced activities of PDHC and $E_{1}$, decreased affinity of PDHC for TPP, and defective activation of PDHC. The decreased affinity of PDHC for TPP shown in cultured lymphoblastoid cells was confirmed in cultured fibroblasts and biopsied muscle. These results suggested that various organs of this patient might show thiamineresponsive $\mathrm{PDHC}$ deficiency resulting in congenital lactic acidemia. In intact cultured lymphoblastoid cells of our patient, addition of a high concentration of thiamine- $\mathrm{HCl}$ or TPP markedly increased the rate of $\left[1-{ }^{14} \mathrm{C}\right]$ pyruvate decarboxylation. These results have been related to the observed decreases in blood lactate and CSF lactate after institution of thiamine therapy in this patient, indicating that this patient is indeed thiamine responsive and that therapeutic treatment with a high dose of thiamine is effective for treatment of congenital lactic acidosis caused by thiamine-responsive PDHC deficiency. No effective therapy for congenital lactic acidemia has yet been established. Therefore, diagnosis of thiamineresponsive $\mathrm{PDHC}$ deficiency is very important, because it may be possible to control lactic acidemia in this type of PDHC deficiency by a large dose of thiamine. PDHC deficiency has been diagnosed by measuring the activity of PDHC at high concentrations of TPP $(0.1-0.7 \mathrm{mM})$ by several groups $(7,9,19,20)$. However, to diagnose PDHC deficiency caused by the decreased affinity of PDHC for TPP, it is necessary to measure activities of PDHC not only at high concentration but also at low concentration of TPP, especially at lower than $1 \times 10^{-3}$ $\mathrm{mM}$ concentration.

Most of the PDHC deficiencies are due to a mutation of $E_{1} \alpha$ gene located in the $p 22.1$ to $p 22.2$ region of the $X$ chromosome $(13,21-25)$. Most of them have been located near the $C$-terminus of $E_{1} \alpha$, and little is known about how the mutations affect the structure or function of the PDHC. In our patient, the mutation is located near the $N$-terminus of $E_{1} \alpha$, and the reading frame remains intact. This mutation was identified at nucleotide position 131 of the $E_{1} \alpha$ subunit, resulting in the substitution of Arg- 44 for His-44. The following lines of evidence indicate that the H44R mutation found in this case accounts for the thiamine-responsive PDHC deficiency. First, results on enzymatic activity suggested that the mutation might be located on $E_{1}\left(E_{1} \alpha\right.$ or $\left.E_{1} \beta\right)$. Second, point mutation was most likely to be located in the coding region of $E_{1} \alpha$ or $E_{1} \beta$ because the defect was associated with normal levels and sizes of $E_{1} \alpha$ and $E_{1} \beta$ proteins. Third, no other mutation was found in the coding region of $E_{1} \alpha$ or $E_{1} \beta$. This mutational change was unlikely to be caused by protein polymorphism because no such polymorphism has been found in any multiple human $E_{1} \alpha$ cDNA sequenced by us or others $(15,21,26-28)$ and because the mutated histidine (amino acid 44) found in this patient is conserved in mammalian $\mathrm{E}_{1} \alpha$ of the porcine muscle, pig heart, and rat liver (29-31). Fourth, the H44R mutation was not found in the $E_{1} \alpha$ subunit of this patient's parents, who had normal PDHC activity, indicating that this mutational change is not a polymorphism but a de novo mutation. These points of evidence support the idea that the H44R mutation results in a decreased affinity of PDHC for TPP and a defective activation of PDHC. Further investigations are required to explain the structure-function implications of the H44R mutant protein.

To our knowledge, until now only three patients with PDHC deficiency clinically improved after supplementation with thiamine $(21,32,33)$. The immunochemical analysis in these three cases has demonstrated different patterns; in patient $1(21)$, the band of $E_{1} \alpha$ subunit was missing, and, instead, an additional band was detected below protein $\mathrm{X}$. However, in patient 2 [patient cited by Old and DeVivo (32)], the amount of $E_{1} \alpha$ subunit was comparable with that in control, but its electrophoretic mobility was altered. In patient 3 (33), $E_{1} \alpha$ and $E_{1} \beta$ were undetectable, and E2 and E3 were decreased. These immunochemical analyses indicated that defects of PDHC in these three patients are due to the different abnormality. Our patient, although responsive to thiamine clinically, may be genetically different from three patients because immunoblot patterns in our patient were essentially the same as in controls, which differs from the previously described cases, and therefore our patient is an original case of thiamine-responsive PDHC deficiency.

Acknowledgment. The authors thank Sei Yanagimoto for technical assistance in culturing fibroblasts.

\section{REFERENCES}

1. Robinson BH 1989 Lactic acidosis. In: Scriver CR, Beaudet AL, Sly WS Valle D (eds) The Metabolic Basis of Inherited Disease, 6th Ed. McGrawHill, New York, pp 869-888

2. Yeaman SJ, Hutcheson ET, Roche TE, Pettit FH, Brown JR, Reed LJ, Watson DC, Dixon GH 1978 Sites of phosphorylation on pyruvate dehydrogenase from bovine kidney and heart. Biochemistry 17:2364-2370)

3. Robinson $\mathrm{BH}$, Chun $\mathrm{K} 1993$ The relation between transketolase, yeast pyruvate decarboxylase and pyruvate dehydrogenase of the pyruvate dehydrogenase complex. FEBS Lett 328:99-102

4. Duran M, Wadman SK 1985 Thiamine-responsive inborn errors of metabo lism. J Inherit Metab Dis 8(supp! 1):70-75

5. Bakker HD, Scholte HR, Luyt-Houwen IEM, van Gennip AH, Abeling NGGM, Lam 31991 Neonatal cardiomyopathy and lactic acidosis responsive to thiamine. J Inherit Metab Dis 14:75-79

6. Anderson MA, Gusella JF 1984 Use of cyclosporin A in establishing Epstein Barr virus-transformed human lymphoblastoid cell lines. In Vitro 20:856-858

7. Naito E, Kuroda Y, Takeda E, Yokota I, Kobashi H, Miyao M 1988 Detection of pyruvate metabolism of skin fibroblasts with dichloroacetate. Pediatr Res 23:561-564

8. Toshima K, Kuroda Y, Naito E, Yokota I. Ito M, Watanabe T. Takeda E, Miyao M, Nonaka I 1985 Diagnosis of partial deficiency of pyruvate dehydrogenase complex in biopsied muscle. Neurology 35:1670-1672

9. Chuang DT, Hu CWC, Patel MS 1983 Induction of the branched-chain 2-oxo acid dehydrogenase complex in 3T3-L.1 adipocytes during differentiation. Biochem J 214:177-181

10. Ito M, Kobashi H, Naito E, Saijo T, Takeda E, Huq AHMM, Kuroda Y 1992 Decrease of pyruvate dehydrogenase phosphatase activity in patients with congenital lactic acidemia. Clin Chim Acta 209:1-7

11. Atkin BM, Utter MF, Weinberg MB 1979 Pyruvate carboxylase and phosphoenolpyruvate carboxykinase activity in leukocytes and fibroblasts from a patient with pyruvate carboxylase deficiency. Pediatr Res 13:38-43

12. Huq AHMM, Ito M, Naito E, Saijo T, Takeda E, Kuroda Y 1991 Demonstration of an unstable variant of pyruvate dehydrogenase protein $\left(E_{1}\right)$ in cultured fibroblasts from a patient with congenital lactic acidemia. Pediatr Res 30:11-14 
13. Ito M, Huq AHMM, Naito E, Saijo T, Takeda E, Kuroda Y 1992 Mutation of $E_{1} \alpha$ gene in a female patient with pyruvate dehydrogenase deficiency due to rapid degradation of $E_{1}$ protein. Inherit Metab Dis 15:848-856

14. Chun K, Mackay N, Willard HF, Robinson BH 1990 Isolation, characterization and chromosomal localization of cDNA clones for the $E_{1} \beta$-subunit of the pyruvate dehydrogenase complex. Eur J Biochem 194:587-592

15. Koike K, Ohta S, Urata $Y$, Kagawa $Y$, Koike $M 1988$ Cloning and sequencing of $c$ DNAs encoding $\alpha$ and $\beta$ subunits of human pyruvate dehydrogenase. Proc Natl Acad Sci USA 85:41-45

16. Koike K, Urata Y, Matsuo S, Koike M 1990 Characterization and nucleotide sequence of the gene encoding the human pyruvate dehydrogenase $\alpha$-subunit. Gene 93:307-311

17. Bradford MM 1976 A rapid and sensitive method for the quantitation of microgram quantities of protein utilizing the principle of protein-dye binding. Anal Biochem 72:248-254

18. Lowry OH, Rosebrough NJ, Farr AL, Randall RJ 1951 Protein measurement with the Folin phenol reagent. J Biol Chem 193:265-275

19. Robinson BH, Taylor J, Sherwood WG 1980 The genetic heterogeneity of lactic acidosis: occurrence of recognizable inborn errors of metabolism in a pediatric population with lactic acidosis. Pediatr Res 14:956-962

20. Kuroda Y, Kline JJ, Sweetman L, Nyhan WL, Groshong TD 1979 Abnormal pyruvate and $\alpha$-ketoglutarate dehydrogenase complexes in a patient with lactic acidemia. Pediatr Res 13:928-931

21. Endo H, Hasegawa K, Narisawa K, Tada K, Kagawa Y, Ohta S 1989 Defective gene in lactic acidosis: abnormal pyruvate dehydrogenase $\left(E_{1}\right) \alpha$ subunit caused by a frame shift. Am J Hum Genet 44:358-364

22. Dahl HH, Maragos C, Brown PM, Hansed LL, Brown GK 1990 Pyruvate dehydrogenase deficiency caused by deletion of a 7-base repeat sequence in the $E_{1} \alpha$ gene. Am J Hum Genet 47:286-293

23. Chun K, MacKay N, Willard HF, Robinson BH 1991 Pyruvate dehydrogenase deficiency due to a 20-bp deletion in exon 11 of the pyruvate dehydrogenase $E_{1} \alpha$ gene. Am J Hum Genet 49:414-420
24. Brown RM, Dahl HHM, Brown GK 1989 X-chromosome localization of the functional gene for the $E_{1} \alpha$ subunit of the human pyruvate dehydrogenase complex. Genomics 4:174-181

25. Daht HHM, Brown GK, Brown RM, Hansen LL, Kerr DS, Wexler ID, Patel MS, DeMeirleir L, Lissens W, Chun K, MacKay N, Robinson BH 1992 Mutation and polymorphisms in the pyruvate dehydrogenase $E_{1} \alpha$ gene. Hum Mutat 1:97-102

26. Dahl HM, Hunt SM, Hutchison WM, Brown GK 1987 The human pyruvate dehydrogenase complex: isolation of cDNA clones for the $E_{1} \alpha$ subunit, sequence analysis, and characterization of the mRNA. J Biol Chem 262:73987403

27. DeMeirleir L, MacKay N, Lam HWAM, Robinson BH 1988 lsolation of a full-length complementary cDNA for human $E_{1} \alpha$ subunit of the pyruvate dehydrogenase. J Biol Chem 263:1991-1995

28. Ho L, Wexler ID, Liu TC, Thekkumkara TJ, Patel MS 1989 Characterization of cDNAs encoding human pyruvate dehydrogenase $\alpha$ subunit. Proc Natl Acad Sci USA 86:5330-5334

29. Sermon K, DeMeirleir L, Elpers I, Lissens W, Liebaers I 1990) Characterisation of a cDNA for porcine $\mathrm{PDH}-\mathrm{E}_{1} \alpha$ and comparison with the human cDNA. Nucleic Acids Res 18:4925

30. Urata Y, Koike K, Goto S, Koike M 1991 Novel separation and amino acid sequence of $\alpha$ and $\beta$ subunits of pig heart pyruvate dehydrogenase. J Nutr Sci Vitaminol (Tokyo) 37:257-267

31. Matsuda S, Nakano K, Ohta S, Saheki T, Kawanishi Y, Miyata T 1991 The $\alpha$-ketoacid dehydrogenase complexes. Sequence similarity of rat pyruvate dehydrogenase with Escherichia coli and Azotobacter vinelandii a-ketoglutarate dehydrogenase. Biochim Biophys Acta 1089:1-7

32. Old SE, DeVivo DC 1989 Pyruvate dehydrogenase complex deficiency: biochemical and immunoblot analysis of cultured skin fibroblasts. Ann Neurol 26:746-751

33. Bonne G, Benelli C, Meirleir LDE, Lissens W, Chaussain M, Diry M, Clot JP, Ponsot G, Geoffroy V, Leroux JP, Marsac C $1993 \mathrm{E}_{1}$ pyruvate dehydrogenase deficiency in a child with motor neuropathy. Pediatr Res 33:284-288 